\title{
Lembaga Swadaya Masyarakat, Media Massa dan Hak Anak
}

\section{Non Governmen Organization, Mass Media and Child Rights}

\author{
Rafieqah Nalar Rizky* \\ Program Studi Ilmu Komunikasi, Fakultas Ilmu Sosial dan Ilmu Politik \\ Universitas Muhammadiyah Sumatera Utara, Indonesia \\ *Email: rafiqahrizky@gmail.com
}

\begin{abstract}
Abstrak
Tulisan ini ingin mengkaji tentang peran LSM dalam memperjuangkan hak anak dilihat dari perspektif HAM dan demokrasi (dilihat dalam ranah wacana, pembuatan kebijakan dan implementasinya) Penulis mengambil studi komparatif antara Sumatera Utara dengan Jawa Tengah. Dalam hal ini, penulis ingin mengkaji tentang sejauh mana peran LSM mulai dari pembentukan wacana tentang Hak Anak, keterlibatan dalam proses pembuatan perda sampai pada ranah implementasi perda. Tentunya hal ini tidak terlepas dari peran besar media massa untuk mendorong terbentuknya isu menjadi wacana di masyarakat. Hadirnya LSM tidak lepas dari tidakmampunya lembaga publik/lembaga pemerintah untuk menangani berbagai permasalahan yang ada di masyarakat. Kemunculan organisasi-organisasi non pemerintah atau lembaga swadaya masyarakat tidak hanya ada di negara berkembang, hal ini menandakan bahwa LSM memainkan peran yang diterima oleh masyarakat luas tidak hanya di negaranegara yang demokrasinya belum mapan yang ditandai oleh kapasitas negara yang masih terbatas, tetapi di negara-negara yang organisasi negaranya memiliki sejarah panjang dan lebih maju. Dengan kata lain, kelahiran LSM disebabkan karena semakin dirasakannya keterbatasan kapasitas negara dalam mengurusi kepentingan publik yang semakin kompleks.
\end{abstract}

Kata Kunci: Lembaga Swadaya Masyarakat, Media Massa, Hak Anak.

\begin{abstract}
This paper would like to examine the role of NGOs in fighting for child's rights from the perspective of human rights and democracy (discourse, policy making, and implementation). This paper compared between North Sumatera and Central Java. This paper wants to examine the extent to which the role of NGO's ranging from the formation of the discourse on the Child's Rights, involvment of making the local regulation process up to the implementation of local regulations. This is not apart from the mass media's role to encourage the formation of issues into discourse in society. The presence of NGOs can not be separated from the absence of public institutions / government agencies to deal with various problems that exist in the community. The emergence of non-governmental organizations (NGO's) is not only present in developing countries, this indicates a role play of the NGO's is accepted by the wider community not only in the democratic countries which are not yet well established which is characterized by the limited capacity of the state, but in the countries where the organization of the country has a long and more advanced history. In other words, the presence of NGOs is due to the increasing perceived capacity of the state in dealing with increasingly complex public interests.
\end{abstract}

Key words: NGO, Mass Media, Child Rights

How to Cite: Ryzky, R.N., (2017), Lembaga Swadaya Msayarakat, Media Massa dan Hak Anak, SIMBOLIKA, 3 (1): $87-$ 96. 


\section{PENDAHULUAN}

Tulisan ini ingin mengkaji tentang peran LSM dalam memperjuangkan hak anak dilihat dari perspektif HAM dan demokrasi (dilihat dalam ranah wacana, pembuatan kebijakan dan implementasinya Penulis mengambil studi komparatif antara Sumatera Utara dengan Jawa Tengah. Dalam hal ini, penulis ingin mengkaji tentang sejauh mana peran LSM mulai dari pembentukan wacana tentang Hak Anak, keterlibatan dalam proses pembuatan perda sampai pada ranah implementasi perda. Sebelum masuk dalam penjelasan, terlebih dahulu penulis mengajak memahami satu kesamaan definisi tentang LSM. LSM menanggapi berbagai permasalahan yang ada di masyarakat dengan bantuan lembaga dana. LSM merupakan organisasi masyarakat yang memberikan kepedulian terhadap pembangunan baik ditingkat lokal, nasional maupun internasional. LSM merupakan lembaga yang kegiatannya dapat bergerak dalam bidang keagamaan, politik, ekonomi, sosial, budaya, dll

Hadirnya LSM tidak lepas dari tidakmampunya lembaga publik/lembaga pemerintah untuk menangani berbagai permasalahan yang ada di masyarakat. Kemunculan organisasi-organisasi non pemerintah atau lembaga swadaya masyarakat tidak hanya ada di negara berkembang, hal ini menandakan bahwa LSM memainkan peran yang diterima oleh masyarakat luas tidak hanya di negara-negara yang demokrasinya belum mapan yang ditandai oleh kapasitas negara yang masih terbatas, tetapi di negara-negara yang organisasi negaranya memiliki sejarah panjang dan lebih maju. Dengan kata lain, kelahiran LSM disebabkan karena semakin dirasakannya keterbatasan kapasitas negara dalam mengurusi kepentingan publik yang semakin kompleks. Kelahiran LSM pada dasarnya bertujuan untuk memajukan kepentingan kelompok-kelompok marginal atau memajukan isu-isu tertentu secara kategoris pada domain publik yang terabaikan.

LSM di Indonesia, sebagaimana terjadi di negara lainya, terpolarisasi ke tiga kutub. Pertama adalah LSM yang menjadi agen neoliberalisme, dibentuk untuk menggantikan fungsi lembaga-lembaga sosial negara. Lembaga ini merupakan prioritas aliran dana dari World Bank, AUSAID, dan lain-lain lembaga funding internasional. Contoh kegiatan LSM ini adalah penyaluran bantuan, pelatihan, pendidikan, dan lain-lain. LSM ini berjumlah paling banyak. Kedua, LSM yang di danai oleh institusi swasta yang berwatak sosial demokrat. Sesuai dengan karekter fundingnya, LSM jenis ini melakukan kritik reformis terhadap sistem ekonomi, menawarkan solusi berupa perubahan pola hubungan antara negara imperialis dengan negara dunia ketiga, yang intinya memperbaiki ekses kegagalan Neoliberalisme, tetapi tidak menolak neoliberalisme sebagai biang penyakit. Yang terakhir adalah LSM progresif yang sering terlibat dengan gerakan rakyat, relatif memiliki independensi terhadap donor. LSM seperti ini aktif dalam gerakangerakan menolak neoliberalisme termasuk menuntut pembubaran IMF, WB dan lain-lain instrumen imperialis, menuntut penghapusan hutang luar negeri, menolak pemotongan bea impor dan melakukan kritikan keras terhadap rezim yang anti-demokrasi dan pro-kapital. LSM seperti ini sering melakukan aksi dengan mobilisasi massa dan memiliki hubungan organisasional dengan organisasi gerakan rakyat (Temu aktivis LSM, 2002).

Penulis membandingkan Sumatera Utara dengan Jawa Tengah karena di dua kota ini LSM yang bergerak di bidang hak anak samasama mempunyai peran yang besar dalam memperjuangkan hak anak dan berperan sebagai kelompok penekan terhadap pemerintah. Selain itu, jika dihat dari program yang mereka lakukan, kedua LSM ini juga memeiliki kesamaan pada beberapa programnya. Lalu, dua provinsi ini sama-sama 
merupakan provinsi besar dengan tingkat pertumbuhan ekonomi yang cukup tinggi tiap tahunnya dan jumlah pekerja anak di sektor informal yang tinggi pula. Dan sektor-sektor ini belum banyak tersentuh. Dalam hal ini penulis ingin melihat peran LSM dalam ranah pembentukan wacana, proses pembuatan kebijakan, sampai pada tahapan implementasi.

\section{PEMBAHASAN}

Dalam pembahasan ini penulis ingin memberikan ulasan kerangka teoritis tentang LSM dan gerakan sosial. Kerangka teoritis ini penting sebagai panduan atau frame work berfikir dasar dalam melakukan pembacaan terhadap objek permasalahan yang akan dibahas. Penulis menggunakan teori gerakan sosial karena LSM merupakan bagian dari gerakan sosial yang ada di Indonesia.

Pada umumnya Lembaga Swadaya Masyarakat adalah sebuah organisasi yang didirikan oleh perorangan ataupun sekelompok orang yang secara sukarela yang memberikan pelayanan kepada masyarakat umum tanpa bertujuan untuk memperoleh keuntungan dari kegiatannya. Dalam arti umum, pengertian LSM mencakup semua organisasi masyarakat yang berada diluar struktur dan jalur formal pemerintahan, dan tidak dibentuk oleh dan merupakan bagian dari birokrasi pemerintah.

Tipologi atau kategorisasi LSM di Indonesia dikemukakan oleh beberapa ahli. Philip Eldridge dalam Mansour Fakih membaginya dalam pendekatan berdasarkan kegiatannya dan mendefinisikan gerakan LSM Indonesia menjadi 2 kategori. Kategori pertama adalah LSM dengan label "pembangunan". Kategori ini berkaitan dengan organisasi yang memusatkan perhatiannya pada program pengembangan masyarakat konvensional, yaitu irigasi, air minum, pusat kesehatan, pertanian, peternakan, kerajinan dan bentuk pembangunan ekonomi lainnya. Kategori kedua adalah LSM "mobilisasi", yaitu organisasi yang memusatkan perhatiannya pada pendidikan dan mobilisasi rakyat miskin sekitar isu yang berkaitan dengan ekologi, hak asasi manusia, status perempuan, hak-hak hukum atas kepemilikan tanah, hak-hak pedagang kecil, tunawisma dan penghuni liar dikota-kota besar (Fakih, 2008:120).

Masih dalam rangka pendefinisian LSM menurut Eldridge, Afan Gaffar menyebutkan bahwa Philip Eldridge juga membagi LSM berdasarkan tiga model pendekatan dalam konteks hubungan LSM dengan Pemerintah. Pertama, kerjasama tingkat tinggi: pembangunan akar rumput (High Level Partnership: Grassroots Development) LSM yang masuk kategori ini pada prinsipnya sangat partisipatif, kegiatannya lebih diutamakan pada hal-hal yang berkaitan dengan pembangunan daripada yang bersifat advokasi. Kegiatan LSM ini tidak bersinggungan dengan proses politik, namun mereka mempunyai perhatian yang besar untuk mempengaruhi kebijakan pemerintah. LSM jenis ini umumnya tidak begitu besar dan banyak bersifat lokal (Gaffar, 2006:212).

Kedua, Politik Tingkat Tinggi: Mobilisasi Akar Rumput (High level Politics: Grassroot mobilization) LSM dalam katagori ini mempunyai kecenderungan untuk aktif dalam kegiatan politik, menempatkan perannya sebagai pembela masyarakat baik dalam upaya perlindungan ruang gerak maupun terhadap isu-isu kebijakan yang menjadi wilayah perhatiannya contohnya adalah LSP, LP3ES, WALHI, YLKI, YLBHI. Mereka pada umumnya tidak begitusaja dapat bekerjasama dengan pemerintah. LSM dalam kategori ini bersifat advokatif, terutama dalam memobilisasi masyarakat guna mendapat tempat dalam kehidupan politik. Ketiga, penguatan akar rumput (empowerment at the grassroot). LSM dalam kategori ini pusat perhatiannya pada usaha peningkatan kesadaran dan pemberdayaan masyarakat akar rumput akan hak-haknya. Mereka tidak 
berminat untuk mengadakan kontak dengan pejabat pemerintah, mereka percaya bahwa perubahan akan muncul sebagai akibat dari meningkatnya kapasitas masyarakat, bukan sesuatu yang berasal dari pemerintah (Gaffar, 2006: 213).

Ditinjau dari segi paradigmanya LSM di Indonesia dapat dibedakan menjadi tiga. Pertama, berparadigma Konformis (developmentalis), yang visinya berangkat dari asumsi bahwa masalah demokrasi dan kondisi sosial ekonom rakyat sebagai faktor yang inheren dengan kebodohan, kemiskinan, keterbelakangan, dan keterpencilan. Dengan demikian solusinya adalah dengan melakukan perubahan mental atau budaya masyarakat sasaran. Kedua, LSM yang menggunakan paradigma reformis. Kalangan LSM ini melihat kondisi sosial ekonomi dan demokrasi karena tak berfungsinya elemen-elemen sosial politik yang ada, di mana rakyat atau kelompokkelompok masyarakat kurang memiliki akses dan kesempatan untuk berpartisipasi dalam politik dan pembangunan. Makanya pendekatan pemecahan masalah, identik dengan pendekatan kedua dari Eldridge di atas, yakni berupaya menyediakan memfasilitasi kesempatan rakyat untuk berpartisipasi, dengan model perubahan yang diharapkan berupa perubahan fungsional struktural (Fakih, 2008:125).

Sementara paradigma ketiga adalah transformatoris. Gerakan-gerakan LSM seperti ini terasa agak radikal, di mana iklim atau isu keterbukaan dimanfaatkan untuk mencoba membongkar berbagai persoalan sosial, ekonomi dan politik. Sangat kontras dengan LSM berparadigma pertama dan kedua, yang ketiga ini melihat kondisi struktur sosial ekonomi dan politik sebagai hasil pemaksaan negara atau kelompok-kelompok dominan, sehingga oleh karena itu melahirkan ketidakadilan dan ketidakdemokrasian. Oleh sebab itu isu gerakan LSM lebih bernuansa politik, seperti mengambil tema hak azasi manusia (HAM), kesenjangan sosial, gerakan civil society, pelibatan rakyat bahwa dalam proses-proses politik seperti demonstrasi, unjuk rasa, termasuk mimbar bebas, serta berorientasi pada kemandirian rakyat; dengan konfik sebagai pendekatan yang digunakan.

Berbagai gerakan sosial dalam bentuk LSM dan Ormas yang kemudian menjamur memberikan indikasi bahwa dalam suasana yang demokratis maka masyarakat memiliki banyak prakarsa untuk mengadakan perbaikan sistem atau struktur yang cacat. Dari hal seperti itu dapat diambil suatu definisi sementara bahwa gerakan sosial merupakan sebuah gerakan yang lahir atas prakarsa masyarakat dalam usaha menuntut perubahan dalam institusi, kebijakan atau struktur pemerintah. Tuntutan perubahan tersebut biasanya terjadi karena kebijakan pemerintah tidak sesuai lagi dengan konteks masyarakat yang ada. Karena gerakan sosial lahir dari masyarakat maka kekurangan apapun di tubuh pemerintah menjadi sorotannya.

Jika tuntutan itu tidak dipenuhi maka gerakan sosial yang sifatnya menuntut perubahan institusi, pejabat atau kebijakan akan berakhir dengan terpenuhinya permintaan gerakan sosial. Sebaliknya, jika gerakan sosial itu bernafaskan ideologi maka tak terbatas pada perubahan institusional tapi lebih jauh dari itu yakni perubahan yang mendasar berupa perbaikan dalam pemikiran dan kebijakan dasar pemerintah. Namun dari literatur definisi gerakan sosial adapula yang mengartikan sebagai sebuah gerakan yang anti pemerintah dan juga pro pemerintah. Ini berarti tidak selalu gerakan sosial itu muncul dari masyarakat tapi bisa juga dari hasil rekayasa para pejabat pemerintah atau penguasa. Dalam hal ini maka gerakan sosial tidak terbatas pada sebuah gerakan yang lahir dari masyarakat yang menginginkan perubahan pemerintah tapi juga gerakan yang berusaha mempertahankan kemauannya. Michael Useem mendefinisikan gerakan sosial sebagai tindakan kolektif organisasi yang 
dimaksudkan untuk mengadakan perubahan sosial. John Mc Carthy dan Mayer Zald melangkah lebih rinci dengan mendefinisikan gerakan sosial sebagai upaya terorganisasi untuk mengadakan perubahan di dalam distribusi hal-hal apa pun yang bernilai secara sosial. Sedangkan Charles Tilly menambahkan corak perseteruan (contentious) atau perlawanan di dalam interaksi antara gerakan sosial dan lawan-lawannya. Dalam definisinya gerakan sosial adalah upaya-upaya mengadakan perubahan lewat interaksi yang mengandung perseteruan dan berkelanjutan diantara warganegara dan negara (Susanto, 1998:21).

Sementara itu Maslow (1962) mencoba menggabungkan analisis psikologis dan struktural. Ia melihat gerakan mahasiswa dan gerakan sosial lainnya sebagai mewakili suatu generasi baru dengan kebutuhan yang lebih tinggi yang tepatnya karena mereka muncul dalam kesenangan kelas menengah, berada dalam posisi mencari nilai-nilai pascamateri, berkaitan dengan tujuan pemenuhan kebutuhan diri sendiri dan tujuan yang lebih altruistik yang berhubungan dengan kualitas hidup (Fakih, 2008:39).

Sedangkan Escobar dan Alvarez (1992) dalam pengamatannya terhadap gerakan sosial di negara-negara dunia ketiga kontemporer juga menemukan bahwa gerakan sosial itu beralih dari perjuangan kelas ekonomi yang terbatas ke transformasi sosial yang lebih luas. Mereka menyatakan:

Lagipula gerakan sosial tidak dapat didefinisikan semata-mata dalam pengertian strategi ekonomi dan sosial; gerakan sosial itu juga harus ditempatkan dalam domain politik dan kultural. Gerakan sosial saat ini - bahkan gerakan sosial yang semata-mata menempatkan diri dalam gelanggang publik tidak membatasi dirinya dalam kegiatan politik tradisional, seperti yang mengaitkannya dengan partai dan lembagalembaga negara, maka menolak cara kita yang telah berurat akar dalam memahami praktik politik dan hubungannya dengan kultur, ekonomi, masyarakat, dan alam' (Escobar dan Alvarez dalam Fakih, 2008:43).

LSM merupakan salah satu pilar penting dalam transisi demokrasi. Lembaga swadaya masyarakat dan organisasi non-pemerintah merupakan elemen penggerak utama pembentukan masyarakat sipil melalui berbagai kegiatan yang mereka lakukan, kegiatan yang dilakukan oleh lembagalembaga tersebut akan mendukung proses demokratisasi (Mercer, 2002:7). LSM memiliki peran utama sebagai aktor yang memobilisasi tekanan untuk mencapai perubahan. Kelompok yang terorganisasi seperti organisasi petani dan buruh, kelompok pembela HAM merupakan agen yang penting dalam proses perubahan menuju negara yang demokratis.

Peran LSM sebagai pilar demokrasi merupakan suatu hal yang dapat dipahami karena aktifitas-aktifitas yang dilakukan oleh LSM mampu membawa rakyat ke arah yang lebih partisipatoris. Secara lebih rinci peran LSM sebagai pilar demokrasi dapat dijabarkan sebagai berikut (Scholte, dalam Widjajanto, 2007: 82): 1) Fungsi pendidikan yang dikakukan oleh LSM melalui pemberian informasi mengenai nilai-nilai demokrasi dan partisipasi publik dapat meningkatkan awareness rakyat terhadap proses demokrasi yang tengah berlangsung; 2) Organisasi non profit/LSM dapat memunculkan isiu-isu yang perlu didiskusikan. Misalnya, isu lingkungan, hak asasi manusia, kemiskinan, yang nantinya dapat disuarakan kepada pemerintahagar membuat kebijakan yang berpihak pada kepentingan rakyat; 3) Melalui mobilisasi rakyat untuk memaksa sebuah pemerintah lebih transparan dalam menjalankan pemerintahan; 4) Melakukan pemantauan terhadap implementasi dan akibat yang ditimbulkan dari sebuah kebijakan.

Prinsip utama lembaga swadaya masyarakat merupakan sarana pelatihan sebagai proses menuju demokrasi dan 
berpartisipasi untuk mengasah peran rakyat dalam politik. Larry Diamond mengemukakan bahwa perkumpulan yang dibentuk secara sukarela akan membangun sikap dan nilainilai demokratis sekaligus membentuk dan melestarikan civic culture yang akan mendukung terciptanya demokrasi (Noble, 1998: 18-19).

Inisiatif mengembangkan mekanisme yang melibakan LSM dan masyarakat pada mula pertama mendapatkan penguatannya kembali menjelang diberlakukannya Undang Undang No 22 Tahun 1999. Sejak tahun 1999, segenap organisasi non pemerintah dan kelompok masyarakat sipil bergiat mengembangkan diskursus tentang peran serta masyarakat, serta penggalangan dan pengorganisasian kelompok-kelompok masyarakat marginal.

Dalam proses pembuatan kebijakan pembangunan secara keseluruhan, mulai muncul peran subjek-subjek lain diluar negara. Dari subjek besar itu khususnya adalah LSM. Mengemukanya wacana governance menjadi indikator kuat untuk memperlihatkan perubahan tersebut. Governance muncul sebagai sebuah pendekatan yang menekankan perlunya interaksi anatara negara, swasta dan masyarakat sipil (dalam hal ini LSM) dalam arena kebijakan publik. Negara dalam hal ini dianggap tidak akan mampu bertindak sebagai satu-satunya stakeholder karena dipastikan memiliki keterbatasan kemampuan. Dilain pihak, tanpa direkayasa bermunculan banyak subjek-subjek non pemerintah yang justru lebih mampu memberikan pelayanan publik kepada masyarakat, atau LSM yang mampu menciptakan mekanisme internal dalam memenuhi kebutuhan dasarnya tanpa keterlibatan pemerintah.

Geliat wacana dan menguatnya tuntutan peran dari representasi masyarakat sipil untuk turut serta dalam proses perumusan kebijakan mendominasi ruang publik di Jawa Tengah, seiring dengan menguatnya isu local governance. Merespon dinamika tersebut, dialog informal yang setiap malam berkembang di warung-warung pun terseret ke dalam fokus isu tersebut. Peran LSM sebagai organisasi non pemerintah yang dikenal banyak memberikan kontribusi mendinamisir isu-isu di kalangan masyarakat grassroot, kemudian dianggap sebagai hal yang cukup penting.

Setelah isu mengkristal dan membentuk wacana, barulah pemerintah mulai merespon isu tersebut untuk dijadikan kebijakan. Kebanyakan wacana terbentuk melalui media massa karena anggota LSM ini mempunyai jaringan yang kuat di media massa baik media cetak maupun elektronik. Tapi dalam hal proses pembuatan kebijakan, LSM di Jawa Tengah tidak terlibat di dalamnya. Mereka juga tidak terlibat membuat legal drafting untuk diaajukan kepada DPR.

Selanjutnya, LSM yang terdapat di jawa Tengah terlibat dalam Rencana Aksi Kota yang dibuat tahun 2007. Dan sampai sekarang, masalah buruh anak ini kebanyakan ditangani oleh LSM. Terutama buruh anak di sektor informal. Mereka menangani masalah buruh anak dari mulai survey, pendampingan, sampai pada advokasi. Sedangkan pemerintah sendiri belum terlalu memperhatikan masalah buruh anak tersebut. Dengan demikian, LSM di Jawa Tengah hanya terlibat dalam ranah pembentukan wacana tentang pentingnya melindungi hak anak, dan pengimplementasian hak-hak anak yang sesuai dengan visi dan misi awal dibentuknya LSM.

LSM dalam bidang hak anak mempunyai peran yang penting di Sumatera Utara, karena di provinsi ini buruh anak masih menjamur terutama buruh di sektor industri rumah tangga, pertanian dan perikanan.ada juga anak-anak yang bekerja di industri besar meskipun jumlahnya tidak diketahui. Terutama karena beberapa dokumen telah dipalsukan demi melegalkan anak bekerja. Tidak jarang pekerja anak tersebut bekerja 
pada sektor berbahaya tanpa adanya jaminan keselamatan ataupun jaminan kesehatan.

Pemerintah daerah sebetulnya sudah menyadari fenomena ini, walaupun pemerintah terkesan lamban dalam melihat permasalahan anak sebagai sesuatu yang mendesak untuk ditangani. Harus diakui bahwa perlindungan terhadap pekerja anak juga merupakan refleksi pemerintah terhadap perlindungan hak-hak asasi manusia yang masuh bolong-bolong. Jangankan perlindungan terhadap pekerja anak, pekerja dewasa yang sudah notabene dilindungi dengan berbagai macam perundang-undangan serta serikat pekerja dan keberadaannya adalah legal juga mengalami hal yang dialami oleh pekerja anak apalagi pekerja naak yang naif dan keterlibatannya dalam dunia kerja tidak diharapkan sama sekali. Pemerintah memang terkesan selalu berlindung dalam paradigma kemampuan ekonomi yang terbatas serta cita-cita pembangunan yang triccle down effect.

Dengan adanya fenomena tersebut, maka LSM-LSM yang bergerak di bidang hak anak mulai membuat isu tentang pentingnya perlindungan terhadap hak anak. Ini dilakukan dengan kampanye hak anak sejak tahun 1990an. Kemudian beberapa pemimpin LSM mulai membuat wacana buruh anak di media cetak agar menyadarkan masyarakat Kota Medan bahwa masih banyak buruh anak yang bekerja dan dieksploitasi. Beberapa LSM tersebut saling bekerja sama untuk menyuarakan tuntutannya agar didengar pemerintah.

Kemudian pada awal tahun 2001 mereka mulai membuat legal drafting peraturan daerah tentang pencegahan dan penanggulangan bentuk-bentuk pekerjaan terburuk untuk anak tanpa menunggu legal drafting dari DPR. Hal ini dilakukan karena mereka menganggap pemerintah daerah masih belum memberikan tindakan atau penanganan apapun untuk mengurangi jumlah pekerja anak di Sumatera Utara. Setelah draft perda selesesai, mereka mulai melobi anggota DPR dan birokrat lainnya untuk menyetujui draft mereka. Mengapa bukan pemerintah yang membuat draft terlebih dahulu? Karena berdasarkan informasi yang penulis dapatkan dari hasil wawancara dengan salah satu anggota DPR pada saat itu (informasi didapat dari salah satu LSM di Medan), pemerintah mempunyai keterbatasan waktu dan keterbatasan dana untuk mensurvey pekerjapekerja anak yang terdapat di Sumatera utara. Untuk itu, mereka pun akhrinya meminta kerjasama dengan beberapa LSM yang bergerak di bidang hak anak dan menyetujui sebagian besar dari isi draft yang telah dibuat oleh beberapa LSM.

Tahun 2002, pemerintah mulai membentuk Komite Aksi Provinsi Sumatera Utara ini berdasarkan Surat Keputusan Gubernur No. 463/1211/K/Tahun 2002 pada 7 Oktober 2002. Dalam Komite Aksi Provinsi ini diketua oleh Asisten Pembinaan Hukum dan Sosial yang beranggotakan mulai dari TNI AL, Dinas-Dinas di Pemerintahan Provinsi, Perguruan Tinggi, LSM, Organisasi Pekerja, hingga Organisasi Pengusaha. Tugas utama Komite Aksi Provinsi ini adalah menyusun Rencana Aksi Provinsi, melaksanakan pemantauan dan evaluasi atas pelaksanaan Rencana Aksi Provinsi, dan menyampaikan permasalahan-permasalahan yang terjadi dalam pelaksanaan Rencana Aksi Provinsi kepada instansi atau pihak yang berwenang. Setelah 2 tahun dibentuknya komite ini, dan mulai ditariknya pekerja anak dari sektor yang berbahaya, barulah disahkan perda tentang pencegahan dan penaggulangan bentukbentuk pekerjaan terburuh untuk anak di tahun 2004. Kemudian, peran LSM dalam implementasi perda tentang pencegahan dan penghapusan bentuk-bentuk pekerjaan terburuh untuk anak. Dalam hal ini, LSM dan elemen masyarakat lainnya berperan aktif dalam mengimplementasikan perda. Ini terbukti dengan adanya beberapa LSM yang telah melakukan pembinaan terhadap buruh 
anak yang telah ditarik. Mereka melakukan pembinaan di balai latihan kerja (BLK) terhadap 600 buruh anak. Selain itu, salah satu LSM yang telah bergerak dalam bidang hak anak selama 20 tahunan, menjadi koordinator pelaksana implementasi perda ini. LSM juga ikut serta dalam melakukan monitoring terhadap pekerja anak. Dengan demikian, LSM yang bergerak di bidang hak anak yang terdapat di Sumatera Utara berperan aktif memperjuangkan hak anak mulai dari pembentukan wacana, keikutsertaan dalam proses pembuatan kebijakan, sampai pada implementasi kebijakan tersebut.

Akhirnya, penulis menemukan benang merah mengapa LSM yang bergerak dalam bidang hak anak di Jawa Tengah dan Sumatera Utara mempunyai program yang sama dan mempunyai peran yang cukup besar dalam memperjuangkan hak anak. Hal ini dikarenakan LSM-LSM tersebut didanai oleh lembaga internasional yang sama sehingga visi dan misinya pun tidak jauh berbeda. Selain itu, LSM di dua provinsi ini tergabung dalam Indonesia ACTs (Indonesia Against Child Trafficking) yang juga mendapatkan donor dari lembaga internasional yang sama.

Selanjutnya, LSM di dua provinsi ini dalam melakukan pembentukan wacana sampai pada keterlibatan dalam implementasi dilakukan dengan cara yang hampir sama, seperti: pertama, melacak melalui menampung semua informasi, melacak informasi, melakukan investigasi, mengadakan diskusi, menyimpulkan dan menganalisis kasus-kasus buruh anak. Serta mengungkapkan kasus tersebut melalui penelitian, polling dan kajian. Dan kemudian disosialisasikan kepada publik melalui melalui forum warga, misalnya forum PKK (di RT dan RW), forum diskusi, dan juga melalui media cetak maupun elektronik, seperti di koran dan dialog interaktif di radio, aksi langsung dilapangan, yang semuanya itu khusus tentang pendidikan. Kedua, Pemantauan terhadap implementasi kebijakan yang ada di dua provinsi, yaitu melakukan monitoring secara langsung di beberapa titik industri yang mempekerjakan buruh anak. Ketiga, Penekan (Pressure) terhadap kebijakan, yaitu melakukan kampanye (kampanye melalui media massa yang ada seperti koran, radio dan televisi), membuat Ranperda Tandingan, aksi (merupakan alternatif terakhir), melakukan riset (survey) dalam rangka memberikan pressure kepada pemerintah. Keempat, kendala-kendala yang dihadapi dalam pelaksanaan pengawasan terhadap implementasi kebijakan pendidikan di Kota Malang, adalah ketika pemerintah tidak lagi memperhatikan tuntutan dari masyarakat, dan tidak ada monitoring secara investigatif dari DPRD, Diknas semaunya sendiri dalam mengambil kebijakan. Terakhir, peran LSM dalam melakukan pengawasan terhadap implementasi kebijakan pemerintah Sumatera Utara dan Jawa Tengah cukup terorganisir dengan baik. Hal ini terlihat pada perannya dalam melakukan pengawasan, pemantauan, maupun melancarkan pressure terhadap kebijakan pemerintah.

Lembaga HAM/LSM yang bergerak di bidang HAM yang memberi advokasi hak-hak anak, mereka harus mengidentifikasi dan menggarisbawahi untuk kegagalan sistem hukum dan policy yang sudah ada dalam menghargai hak-hak anak serta mengajukan usulan langkah-langkah memperbaikinya. KHA adalah sebuah pandangan yang komprehensif, tidak hanya berkaitan dengan hak-hak sipil dan politik tapi juga soial, ekonomi dan kebudayaan. Perlindungan atas hak-hak tersebut harus diintegrasikan ke dalam mandat lembaga.

Lembaga HAM untuk anak harus mempertimbangkan dan memikirkan serta mengimplementasikan bagaimana keempat prinsip di atas dapat direalisasikan dan menjiwai atas semua hak-hak anak.

Lembaga HAM anak dapat mempromosikan melalui aktivitas-aktivitas sebagai berikut: 1) Analisa sistem perundang- 
undangan yang ada, kebijakan dan implementasinya. Apakah sistem perundangundangan serta policy tersebut sudah memenuhi KHA ?; 2) Menjalankan investigasi, penyelidikan dan reporting atas aspek-aspek kebijakan atau implementasi yang berakibat pada anak termasuk di dalamnya mengajukan alternatif atau ide-ide baru bagi perbaikan; 3) Memberi komentar atas rancangan legislasi baru yang sedang diajukan sedini mungkin yang didasarkan pada hak-hak anak yang tertera dalam KHA; 4) Menjalankan investigasi resmi atas laporan kekerasan dan penelantaran terhadap anak, baik laporan itu datang dari anak maupun dari orang dewasa yang peduli.

Peran LSM sangat penting. Merekalah yang turut mendorong proses demokratisasi dan partisipasi warga masyarakat. Hal itu mereka lakukan melalui pemberdayaan masyarakat, pendampingan, advokasi dan mendorong wacana partisipasi masyarakat. Dengan dukungan finansial dari donor dan pengalaman bekerja sebagai pendamping masyarakat, sejumlah LSM dapat secara efektif mendukung peningkatan kapasitas fasilitator lokal. Selain itu mereka juga dapat menggerakkan dialog dan kerja sama multistakeholder sebagai upaya mengerahkan sumber daya lokal.

Sayangnya, dinamika pengetahuan di kalangan LSM seringkali tidak sesuai dengan percepatan kebutuhan masyarakat. Misalnya dalam teknik monitoring dan evaluasi oleh warga masyarakat yang sampai sekarang masih perlu disesuaikan konsep dan metodenya. LSM sebagai mediator antara kebutuhan warga masyarakat dengan penentu kebijakan seringkali juga terjebak oleh wacana yang terlalu luas dan cenderung mengabaikan potensi pengetahuan lokal yang sudah dimiliki oleh masyarakatnya. Selain itu, program LSM yang terikat waktu kontrak dengan donor menjadi kendala, karena kadang kurang sesuai dengan waktu pendampingan yang masih dibutuhkan oleh masyarakat.
Selain itu, peran LSM dalam proses transisi demokrasi di Indonesia mulai diragukan ketika kemunculan LSM ini dipengaruhi oleh aktor eksternal yaitu funding internasional. Proses kemunculan LSM di Indonesia kebanyakan dikarenakan oleh aktor eksternal tersebut seperti respon terhadap kebutuhan donor untuk menyalurkan bantuannya dan menyebarkan nilai-nilai demokrasi dan pembangunan yang dianutnya. Berbeda dengan kemunculan LSM di Eropa yang cenderung terjadi karena adanya kekuatan internal yang menginginkan perubahan tatanan sosial politik. Di negaranegara Eropa rakyat secara sadar membentuk LSM untuk melindungi hak dasarnya dari tindakan dan kebijakan yang diambil oleh pemerintah, serta berusaha membuat pemerintah mempertimbangkan pertanggungjawaban tindakannya kepada rakyat dalam pengambilan keputusan. Sementara itu, kemunculan LSM di Indonesia terjadi karena adanya upaya penyebaran gagasan-gagasan neoliberal, melalui suatu konsep yang mendukung proses desentralisasi akan merangsang pertumbuhan ekonomi dan demokratisasi. Pengaruh lain dari pihak asing adalah pembentukan LSM berupa pemberian dana bantuan untuk advokasi dan pembangunan kapasitas LSM yang diberikan oleh institusi-institusi internasional karena lemahnya LSM di Indonesia. Selain itu, LSM yang menerima donor dari lembaga asing terus membuat kebijakan-kebijakan ataupun program-program dengan harapan bahwa bantuan dana akan mengalir terus. Karena LSM saat ini kebanyakan menerima bantuan donor eksternal, hal ini memungkinkan melemahnya hubungan antara LSM dengan masyarakat yang seharusmya mereka wakilkan. Sehingga lama kelamaan hanya sedikit LSM yang terbentuk karena mobilisasi masyarakat yang sebenarnya akan lebih efektif jika LSM tersebut terbentuk karena adanya permasalahan yang harus dipecahkan bersama-sama. 


\section{SIMPULAN}

Akhir dari tulisan ini, penulis ingin mengungkapkan keberadaan LSM harus menjadi garda terdepan dalam melakukan advokasi terhadap hak-hak buruh anak. Bukannya hanya itu saja peran lebih dituntut kalangan LSM untuk melakukan pendampingan agar kelak buruh anak bisa memiliki kehidupan yang layak serta kwalitas dari segi pendidikan. Pasang surut dalam melakukan advokasi akan mendapatkan penghalang besar yaitu kepentingan pengusaha untuk memanfaatkan. Tentunya dalih-dalih untuk pendapatan kas daerah menjadi senjata ampuh mencuci otak pemerintah. Tetapi yang harus diperhatikan adalah kekuatan suatu bangsa dan negara apabila generasi penerusnya memiliki kwalitas keilmuan atau pengetahuan yang bisa dihandalkan. Permasalahnya pemerintah kurang memahami hakekat dari renungan barusan. Memang benar tidak hanya pemerintah yang bertanggung jawab dalam mengurangi dan menghilangkan pekerja anak atau buruh anak. Peran keluarga harus mampu menjadi pondasi utama dalam membentuk mental dan kematangan secara keilmuan. Tetapi peran pemerintah jangan lepas tangan tanpa berbuat apa pun dalam mengatasi eksploitasi buruh anak. Sekali lagi, LSM dan pemerintah harus seiring berjalan dan sinergis dalam menyelesaikan masalah buruh anak, bukan malah menjadi musuh seperti kucing dan tikus. Syarat utama keterbukaan dan komunikasi yang dilakukan bukan egos sentris lembaga dan masingmasing personal baik LSM maupun pemerintah atau birokratnya. Intinya kita harus optimis dalam mewujudkan gerakan bebas buruh anak sehingga kita tidak akan menemui lagi pemarginalan buruh anak baik dalam tindakan kekerasan, eksploitasi, dan lain-lain. Terlepas dari apapun peranan mereka (LSM) yang jelas dalam periode sepuluh sampai lima belas tahun terakhir ini telah banyak bermunculan LSM. LSM tidak hanya menawarkan alternatif untuk kegiatankegiatan yang bersifat penyadaran dan pembelaan kepentingan umum. LSM-LSM tersebut berharap dapat memberdayakan masyarakat dalam berhadapan dengan pemerintah, karena dalam hal ini pemerintah mempunyai kekuatan yang besar dalam fungsi kontrolnya terhadap masyarakat. Tetapi ada juga LSM yang bergerak dalam bidang-bidang yang merupakan kepentingan hajat hidup orang banyak. Secara umum dikatakan bahwa kemunculan LSM disebabkan oleh dua hal, kebutuhan masyarakat untuk menyuarakan aspirasinya serta adanya dana bantuan eksternal dari luar negeri yang disalurkan langsung kepada masyarakat.

\section{DAFTAR PUSTAKA}

Fakih, M., (2008). Masyarakat Sipil untuk Transformasi Sosial. Yogyakarta: Insist Press

Gafar, A., (2006). Politik Indonesia: Transisi Menuju Demokrasi. Yogyakarta: Pustaka Pelajar

Mercer, C., (2002). NGOs, Civil Society and Democratization: A Critical Review of The Literature. Vol 2/1

Susanto, A., (1998). Masyarakat Indonesia Memasuki Abad ke Dua Puluh Satu. Direktorat Jendral Pendidikan Tinngi Departemen Pendidikan dan Kebudayaan.

Temu aktivis lembaga swadaya masyarakaat (LSM) dari berbagai kota di Jawa, yang diselenggarakan Harian Umum Kompas, bertempat di Puncak, Jawa Barat, pada 31 Oktober sampai 1 November 2002. Pertemuan bertopik "Menggugat Eksistensi dan Peran LSM"

Widjajanto, A., dkk, (2007). Transnasionalisasi Masyarakat Sipil. Yogyakarta: LKis 